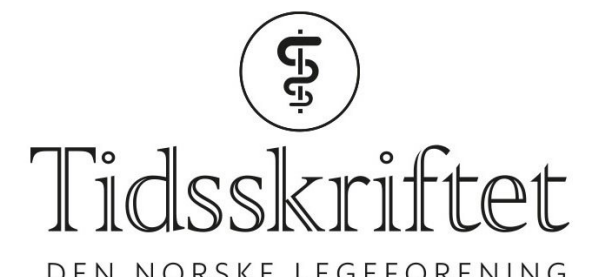

DEN NORSKE LEGEFORENING

\title{
Talerør for taus pasientgruppe
}

INTERVJU

MARIT TVEITO

E-post: marit.tveito@me.com

Hudlege Anne Lise Helgesen ble så engasjert av fortvilte pasienter med tabubelagte sykdommer i underlivet at hun både startet et forskningsprosjekt, en interesseforening og tok ordet i Stortinget for å tale deres sak.

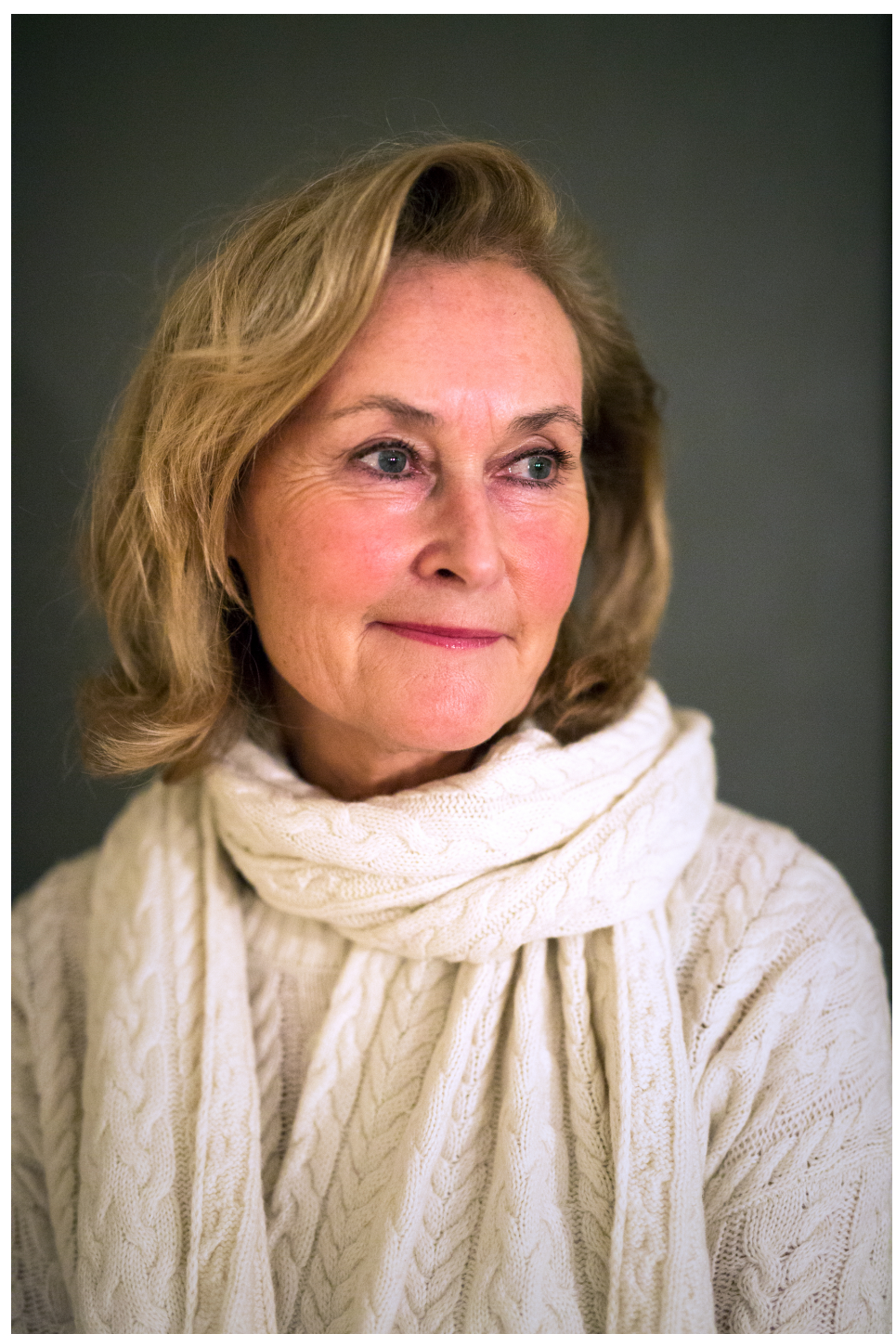


En dyktig kliniker og forsker, som alltid setter pasientene fremst og ikke er opptatt av å fremheve seg selv, sier kollegene om Helgesen. På stillfarent vis har hun løftet frem en pasientgruppe som ofte faller mellom to stoler, pasienter med vulvaplager, og de har blitt hennes faglige livsoppgave. Helgesen har gjennomført forskningens gullstandard, en randomisert kontrollert studie, den første på sitt område. Hun omtales som en raus og flott kollega, og som en utålmodig, målrettet forsker med stor gjennomføringsevne.

Hun inviterer hjem til eneboligen på Smestad. Huset er nytt og funkisaktig i stilen, et av mange like hus i det som sikkert har vært en eplehage en gang. Kaffe og småkaker kommer på bordet. Hun liker å lage mat, og kjøkkenet er romslig. Annenhver uke har hun og en venninne middagsklubb, hvor de tar med en «hemmelig» gjest hver. Den eneste regelen er at det skal være to retter de aldri har laget før. Ifølge Helgesen blir det oftest suksess, av og til fiasko.

\section{Aldri angret}

- Hvorfor ble du lege?

- Faren min var lege, og broren min valgte å følge i hans fotspor. Jeg hadde egentlig lyst til å bli journalist eller dyrlege. Men det ble medisin.

- Hva med moren din?

- Hun var lærer, men stort sett hjemmeværende. Søsteren min er fysioterapeut. Det går mye i helsearbeid i familien, men ingen av de to guttene mine har valgt å bli lege. Begge har studert $ø$ konomi, og den ene studerer jus i tillegg.

Selv er hun fornøyd med yrkesvalget.

- Jeg har aldri angret en dag på at jeg ble lege. Det må jeg si. Det henger nok sammen med at jeg har en stilling med mye autonomi. Jeg er en av de få hudlegene ved Rikshospitalet som har en deltidsavtale. Det var Ole Fyrand som fikk til det i sin tid. Han var veldig for at kvinnelige leger skulle ha tid til barn og familie.

\section{Anne Lise Helgesen}

Født 5. oktober 1960

Cand.med. Universitetet i Bergen 1986

Spesialist i hud- og veneriske sykdommer 1997

Ph.d. 2016

Arbeider $50 \%$ som postdoktor, $10 \%$ i klinisk stilling ved Vulvaklinikken og $40 \% \mathrm{i}$ avtalepraksis

- En moderne sjef?

- Han var for foreldrepermisjon, selv om vi ikke hadde formelle rettigheter, og oppfordret til minst ett års permisjon. Han var en flott leder, med evne til å se den enkelte.

Morgenmøtene var inspirerende, han snakket aldri om penger, bare om fag. Jeg har jobbet $\mathrm{i}$ 25 år ved Rikshospitalet, og nå snakker vi nesten bare om økonomi. Det er ille hvordan dette styrer hverdagen. Før var pasienten i fokus.

\section{Vulvaklinikk}

Helgesen var med på å starte Norges første vulvaklinikk på Rikshospitalet i 2003.

- Det ble spurt på morgenmøtet om en hudlege kunne være med på å starte en vulvaklinikk. Alle så ned i bordet. Jeg hadde allerede jobbet et år ved gynekologisk avdeling, rakte opp hånden og meldte meg. Vi var tre stykker: Rolf Kirschner som gynekolog, jeg som hudlege og Karin Edgar som spesialist i begge deler. Vi startet Norges første tverrfaglige vulvaklinikk 
med én dag i uken til disse pasientene. Karin Edgar var svensk, og hadde mye erfaring fra Sverige.

Pasientene kan ha ulike tilstander som gir smerteplager i underlivet og som ikke minst er svært tabubelagte sykdommer. Dette er et område innen medisinen som Helgesen åpenbart bryr seg mye om.

- I Norge har vi en klinikk på Oslo universitetssykehus og en mindre enhet i Trondheim. En 40 \% legestilling skal betjene hele landet. Regjeringen i Sverige påla myndighetene i 2016 å gjøre en undersøkelse av vulvaklinikker. De ville utrede helsetilbudet til kvinner. De har klinikker i mange fylker med lege, sosionom, psykolog, sykepleier og fysioterapeut som jobber i team. Det er dette jeg drømmer om for vår vulvaklinikk. Vi har jobbet siden 2003 og fikk ikke noen ekstra ressurser før i 2018. Gjennom hele perioden har vi vært

nedleggingstruet og en salderingspost, mens ventelistene eksploderer. I starten hadde vi tre års ventetid. Det løste sykehuset ved kun å ta imot henvisninger fra spesialist. Det har vært mye arbeid å få til en økning fra $30 \%$ til $40 \%$ legestilling. Problemet for vulvaklinikken er at fagfeltet ligger i skjæringspunktet mellom gynekologi og dermatologi. Det er ingen som føler det fulle og hele ansvaret for pasientene, og de faller mellom to stoler.

Konsultasjonene er dessuten veldig tidkrevende og gir lite DRG-poeng, så det er lite attraktivt å gi et poliklinisk tilbud.

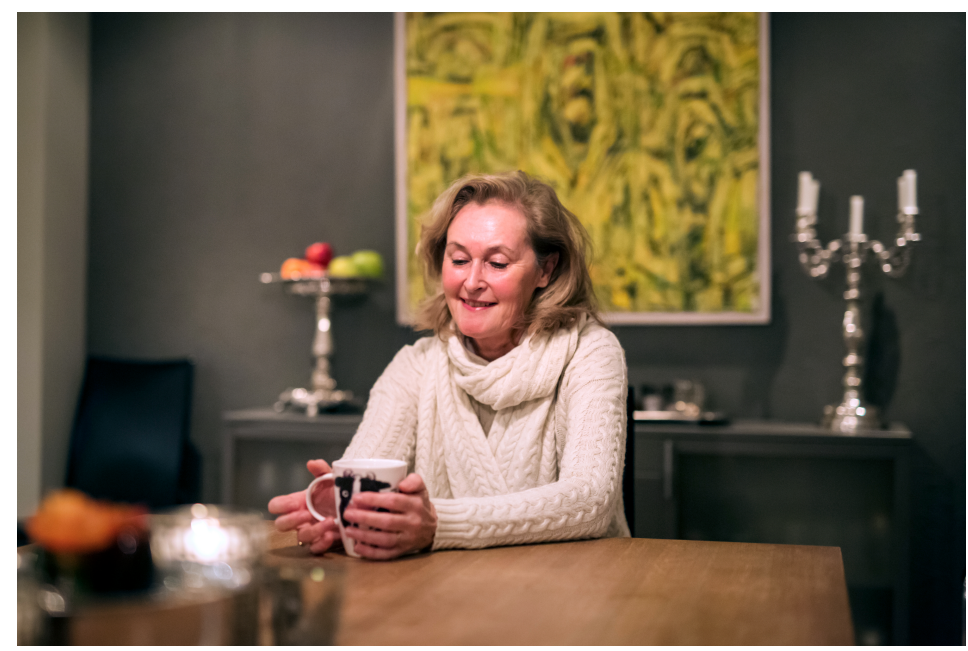

- Er det grunnen til at disse pasientene ikke prioriteres?

- Kanskje, og så er dette sykdommer som ikke har høy status. Disse kvinnene har ingen pasientorganisasjon. Det er så tabubelagt at de ikke tør å snakke om det. Det blir et problem som er lett å skyve unna. Det er ingen andre enn oss som kan tale deres sak.

- Det blir ikke noe oppslag i pressen om vulvasykdommer?

- Det er vanskelig å stå frem og fortelle om denne type plager. De forteller det knapt til sin nærmeste venninne. Og det er lite kunnskap blant folk flest om dette. Mange vet knapt at det er forskjell på vulva og vagina. Nyttårsaften 2017 bestemte jeg meg for å fronte temaet. Forsettet gikk ut på at i 2018 skulle jeg bruke mye krefter på dette. Og det har jeg gjort. Jeg tror jeg pådro meg litt atrieflimmer av det, ler hun tørt.

- Først bestemte vi oss for å etablere en tverrfaglig interesseforening for helsepersonell som er interessert i feltet. Vulvaforum har nå 120 medlemmer og består av gynekologer, sexologer, fysioterapeuter og hudleger. Vi møtes to ganger i året, og styret har bestemt seg for å lansere nettsiden Vulva.no. Den skal være rettet mot både pasienter og helsepersonell. Det skal også være informasjon om hvor man kan henvende seg, med oversikt over både gynekologer og fysioterapeuter som har kunnskap og interesse for dette fagområdet. Behovet er stort.

- Er det vanskelig å kartlegge tabubelagte sykdommer?

- Hver gang vi fronter poliklinikken, øker ventelistene dramatisk. Jeg får ukentlige brev fra fortvilede pasienter som tar direkte kontakt fordi de ikke har fått noen til å henvise.

- Det må være vanskelig å se behovet uten å ha ressurser til å hjelpe alle? 
- Vi prøver jo alltid å bistå så godt vi kan. Drømmen min er at vi skal etablere en stor vulvaklinikk med tverrfaglige ressurser. Satellitter rundt på ulike sykehus hadde også vært fint. Det som skjer nå, er at de private aktørene gir tilbud. De har skjønt at det foreligger et udekket behov. Det lanseres pakkeløsninger for 12 ooo kroner med et lite opplegg som inkluderer noen legetimer og kanskje konsultasjoner hos en fysioterapeut. Mange av pasientene er unge jenter. De har ikke råd til dette. Nesten halvparten av pasientene med vulvaplager er i alderen 17-25 år som ikke kan ha samleie. Det er ganske ille i denne perioden av livet. Det handler oftest om vulvodyni, en spenningstilstand med smerter. Det rammer ofte «flinke» piker, mange er legestudenter og jusstudenter. Tilstanden er vanligere enn man tror. Sannsynligvis vil 10-15\% av alle kvinner i Norge oppleve perioder med kroniske underlivssmerter i løpet av livet.

\section{Til Stortinget}

Helgesen liker å ha en plan.

- Vi etablerte som nevnt Vulvaforum, begynte å jobbe med nettsiden, og så dro jeg til Stortinget i mai. Jeg liker ikke å holde foredrag, så det kostet mye, men jeg gjennomførte det. Helseministeren har laget en overordnet strategisk plan for seksuell helse, Snakk om det, som skal gjelde for noen år fremover. Da tenkte jeg med en gang på vulvapasientene mine, og jeg fikk audiens sammen med mange andre organisasjoner.

- Du forberedte deg godt?

- Vi var 17 personer fra ulike organisasjoner, alt fra Sanitetsforeningen til Amnesty International. Alle hadde tre minutters taletid. Vet du hvor mange politikere som kom?

- Ikke så mange?

- Bare han som hadde invitert og en mannlig politiker til. Jeg tror kanskje ikke seksuell helse skaper den store interessen. Så dro jeg til Arendalsuka på høsten. Der fikk jeg også mulighet til å snakke om vulvasykdommer. Dit kom det imidlertid ganske mange, jeg hadde mer tid og kunne fortelle om hverdagen til disse pasientene. Da satt det noen og gråt i salen. Håpet er jo at en eller annen politiker, mellom oss sagt, skal ha eller i det minst kjenne noen som har denne type lidelse, humrer hun.

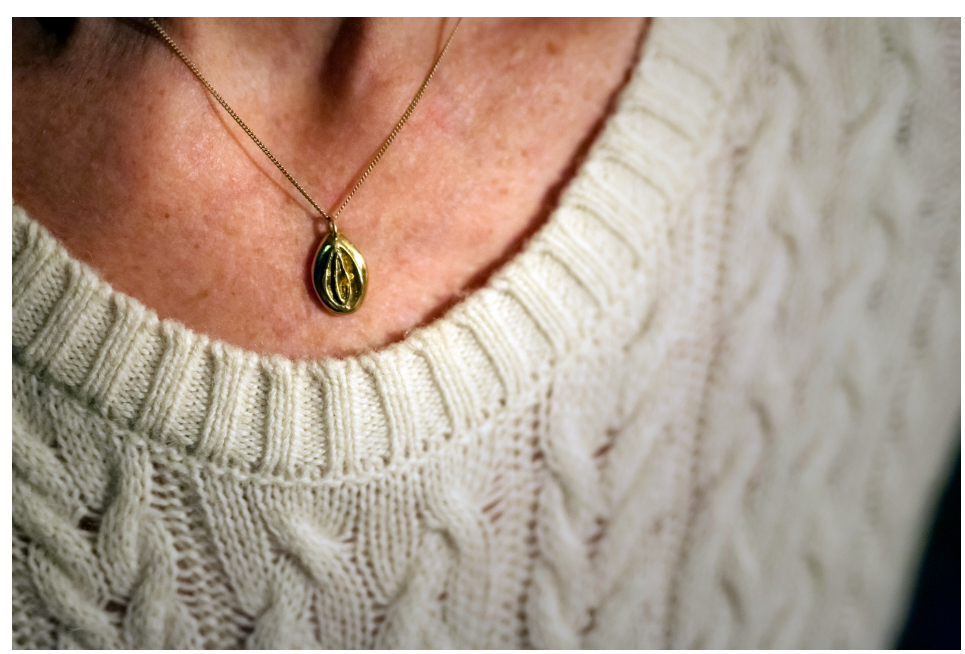

- Man ønsker jo ikke at noen skal være syke, men det hadde kanskje hjulpet om en politiker virkelig fattet interesse - da kunne bevilgningene komme.

- 2018 ble altså vulvaåret?

- Ja, det har det virkelig vært. Jeg holdt nylig Norges første kurs i vulvasykdommer. Jeg la ut kurset med 6o plasser før sommeren, og i løpet av to uker var det fulltegnet, med 30 stykker på venteliste. 


\section{Først i verden}

- Hva handlet doktorgraden din om?

- Den handlet om lichen planus i underlivet hos kvinner, hvor både vulva og vagina får åpne sår og kan gro igjen. Jeg begynte å forske på dette for ti år siden på Vulvaklinikken. Jeg var på et foredrag hvor en tannlege fortalte om fotodynamisk terapi på oral lichen planus med god effekt. Jeg har syntes så synd på disse kvinnene som har hatt store plager og lite behandlingstilbud. Nesten samtidig startet Nasjonal kompetansetjeneste senteret for kvinnehelse ved Rikshospitalet. Jeg tok kontakt, fikk med meg en veileder som hadde drevet med fotodynamisk terapi ved Radiumhospitalet, og det endte med at jeg fikk en $50 \%$ stipendiatstilling. Det var min idé, og jeg har vært nokså alene om prosjektet. Det var første gang i verden at den behandlingen ble testet ut mot lichen planus i underlivet. Vi sammenlignet med bruk av lokale steroider, og fant at fotodynamisk terapi ga langtidseffekt hos ca. $60 \%$ av pasientene. Nå er det blitt en etablert behandling på Oslo universitetssykehus.

- Det var ikke gjort en eneste randomisert kontrollert studie på denne pasientgruppen?

- Nei. Denne tilstanden blir trukket frem på vulvakongresser som den som er vanskeligst å behandle. Ingen har grepet ordentlig fatt i denne pasientgruppen.

- Bortsett fra deg?

- Det er jo litt tilfeldig, men når jeg først går inn for en sak, så gjør jeg det grundig.

Grundigheten preger flere områder av livet. Samtidig med forskningsarbeidet bygde hun hytte. Litt etter litt kom alt på plass.

- Du er glad i fjellet?

- Mer og mer. Der kobler jeg av - selv om papirene iblant blir med. Fysisk aktivitet gir overskudd. Jeg er glad i å gå på tur, på beina og på ski, og liker for øvrig også å sykle. Energi henter jeg også gjennom å reise, til alle mulige steder, en interesse som mine sønner for øvrig har fulgt opp.

Helgesen har fått et stort internasjonalt nettverk og har hospitert hos kolleger både i Storbritannia og USA. I begge sammenhenger har hun blitt invitert til å bo privat. Det ble det flotte opplevelser av.

- I USA bodde jeg hjemme på hestefarmen til en professor. Hun tok meg med overalt og jeg måtte til og med holde en times foredrag på Harvard om forskningen. Jeg inviterte en utenlandsk foreleser til å bo hjemme hos oss da jeg arrangerte vulvakurset.

- Det er hyggelig å bli bedre kjent med sine kolleger. Det kunne vi sikkert gjort mer av.

Publisert: 21. februar 2019. Tidsskr Nor Legeforen. DOI: 10.4045/tidsskr.18.0974

(C) Tidsskrift for Den norske legeforening 2020. Lastet ned fra tidsskriftet.no 